\title{
The Truth Behind Voice and Power in My Feudal Lord: A Speech Act Analysis
}

\author{
Asifa Qasim ${ }^{1}$ \\ ${ }^{1}$ Department of English Language \& Translation Studies, College of Arts and Science, Qassim University, Saudi \\ Arabia \\ Correspondence: Asifa Qasim, Department of English Language \& Translation Studies, College of Arts and \\ Science, Qassim University, Saudi Arabia. E-mail: a.awan@qu.edu.sa
}

Received: June 20, $2020 \quad$ Accepted: July 20, $2020 \quad$ Online Published: July 22, 2020

doi:10.5539/ijel.v10n5p231 URL: https://doi.org/10.5539/ijel.v10n5p231

\begin{abstract}
Female writers use autobiography to express their experiences, deference, and inner-conflicts. They describe their connection to different events and people in domestic or social context to explain their feelings and complexity of their lives. This study analyzes the way Durrani constructs norms of gender and power in her autobiography, My Feudal Lord. The paper imports Searle's theory of speech act analysis to discover the way the author creates and performs gender in the domain of power through textual interactions. Durrani achieves the effect of patriarchy through frequent use of directives, expressives, and commissives by her husband through employing direct language. The husband openly expresses criticism, blame, complain, and acknowledgement in his interactions which validate his authority over his wife. The striking feature of the wife's speech is even more frequent use of directives as compared to the husband. However, the major gender distinction was reflected in the use of directives. The husband used more commands and the wife asked more questions. Another major difference was that of commissives which occurred half of the times in the wife's speech as compared to her husband's speech. She hardly used any apologies or compliments which shows her diminishing submission to her husband's authority. Her expressives also reflect her firm attitude and courage to take risk of protesting against her physically and socially more powerful husband.
\end{abstract}

Keywords: autobiography, speech act analysis, gender representation, power, pragmatics

\section{Introduction}

In family interactions, speech acts, uttered by a spouse, such as orders, requests, promises, threats and compliments are meant to influence the other spouses' actions and behaviors. Studies on conjugal talk have demonstrated that the investigation of communication between wife and husband aids in determining the quality and nature of their relationship through their utterances. For research purpose, the frequencies of the verbal behaviors are generally observed and coded, and then employed to decide submission or dominance of a spouse. Even as the coding format is dependable in its capacity to determine definite behaviors, the strength of the coding principle is rather hard to evaluate due to an inadequate investigation of the particular abstract reason behind the procedures chosen to determine power differences. Being skilled analysts of language, researchers, can be depended upon to decode and interpret language behavior (Donnelon, Gray, \& Bougon, 1986; Gronn, 1983; Rosen, 1985). However convincing, such an approach disregards a more topical body of sociolinguistic discoveries emphasizing that a good deal of speech behavior is repetitious, and that several quantifiable, discrete linguistic variables can be reliably observed and identified (Hudson, 1990). Whilst substantially inconsistent in practice like in everyday discourse, language customs are frequently predictable and routinized in theory. Everyday conversation, as it engages widespread association of roles, is a strong framework to investigate power relations. The flow of conversation leads to primary interactional conventions and identities that determine relationships in an extensive sense.

Dominance theory (Mazur, 1983; Lee \& Ofshe, 1981; Ridgeway, 1984) deals with ethological examinations of behavioral pecking orders in animal species and relates the framework to human communication. For example, gaze performs a notably comparable function in dominance of the interactional contribution (Exline, Ellyson \& Long, 1975; Jay, 1965). Further behavioral indications employed by human beings to signal dominance including interruptions, voice tone, spatial proximity, and body posture have also been investigated (Rosa \& 
Mazur, 1979). Yet a considerable limitation of theory of dominance is that it proposes a description of human interaction that is eventually similar to the watching of a silent show. Although viewers can comprehend most of what becomes obvious by making presumptions based upon gestural, proximal, intonational, and facial cues yet an examination of the function of language in the ratification of power remains missing. This is a major shortcoming, for language is most information-rich and most critical source of communication among human beings.

A speech act analysis theory, nevertheless, scrutinizes language directly. It is commonly expected that individuals having an association with us will offer us support and assertion in our everyday interactions. Therefore, politeness signifies "phrasing things in such a way as to take into consideration the feelings of others" (Brown \& Gilman, 1991). The decisive function of politeness can be observed in relation with a given set of interactional speech acts. However, conflicting conditions are widespread and frequently inevitable in a relationship indicated by acts of criticizing, contradicting, disagreeing, imposing, interrupting, asking for a favor, borrowing, embarrassing, and requesting information. This study has primarily brought in linguistic research into the sphere of power in matrimonial communications. It is simple to spot speech acts in interactions as they are generally explicit and conscious and hold a traditional meaning. This paper does not explore speech acts with reference to their internal nature or the purpose of the speaker in employing them. The major focus is on the exploration of power in family relations as revealed indirectly through language i.e., speech acts.

This paper employs the externally visible nature of linguistic speech acts to explore Durrani's autobiography, My Feudal Lord, for the kind of speech acts in the conversations between the lead characters, husband and wife. The paper examines the way standards of power and gender are constructed and executed through conversations. Speech act analysis converts conversation into actions which define the objectives of the participants while the capacity to effect these actions is understood as power. The study explores how far the use of particular speech acts aid in characterization in relation to gender and power relations.

The plain response to the question on the relationship between speech acts and power is that all categories of power share one common aspect i.e., the capacity of the individual in power to control the behaviors and actions of others. As a result, though a domineering husband seems to be entirely commanding in comparison to his docile wife, instances of the wife directing the husband are not difficult to find in Durrani's autobiography. She is found claiming authority by claiming the privileges permitted to a powerless wife. This study has attempted to analyze how power dynamics in the marital relationship can be revealed through the use of language.

\section{Literature Review}

\subsection{Gender Representation in Female Authored Literature}

The issue of gender representation in literature is addressed through how the genders are portrayed in language or how the genders communicate themselves. Dale Spender attends to the matter of males being somebody "who have made the world which women must inhabit" (Spender, 1990, p. 93). This world, depicted this way, can be described as the world of language, and hence the tool shaping "the limits of our world, which constructs our reality" (Spender, 1990, p. 94). Such restraining language obligates women into a scheme of individual speech that is not essentially accurate to their character, which not only the linguists have addressed but has also been tackled by literary critics like Virginia Woolf in Women and Fiction (Woolf, 1990) and in The Angel in the House (Woolf, 2004) in the first half of the 20th century. In afore mentioned essays, Woolf talks about the effort women writers make as the conventions of writing, defined by men's mind, restrict the women. In the initial case, this is "the very form of the sentence [that] does not fit her. It is a sentence made by men; it is too loose, too heavy, too pompous for a woman's use" (Woolf, 1990, p. 50); however, Woolf also experienced restriction in her work by what she named "ghosts" or "phantoms" (Woolf, 2004, p. 189), which, she felt was the controlling force in her own mind that would evaluate her own work by standards set by men (Woolf, 2004). She believed that in order to write without restraint and following their womanly temperament, women would have to gain skill of negating the role culture wanted from them. Similarly, gender issues have to face the problem of clichés and gender stereotypes existing in society. Thus, a society's philosophy of gender may serve as the general denominator linking a range of issues.

\subsection{Speech Acts in Literature}

Speech acts put actions in words. They may not mention something but even so makes something to take place. They perform something that may well do further things later on. It means saying things signifies doing things. Three types of speech acts may be recognized in relation to literature as identified by Miller in 2005. First of all, the writer's work of writing a text is an act that acquires the shape of setting details in a certain manner. Second, the characters or narrators in a narrative text may pronounce speech acts which are a type of performing acts 
with language — declarations, promises, excuses, acts of bearing witness, denials, decisions, and lies. These type of speech acts constitute key moments in the characters' or narrator's way of life. Third, the reader, in acts of informal comment, criticism, or teaching, may act things by placing a reading into terms in his or her turn. Writing or teaching criticism or simply having conversation about a text is an act that may generate additional things in its turn.

\subsection{Autobiography}

Timothy Dow Adams (1994) has pointed out that memoirs have conventionally been considered as text narrating true-life story. This classification has been provoked by and sequentially maintained by the vision about autobiography as not being a creation of the biographer, rather a documentary account of his personal life. Alan Collett (1989) asserts that the reader of "documentary report" presumes that the expressions in the life history "possess a truth value" that in other words, they speak about a truth existing outside of the book and this connection can be true or fallacious. The reader expects that whatever a writer narrates about her or his life matches up to the things as they actually were. Hence, one of the attractions in reading a life story is rooted in the desire of the reader to discover something with reference to actual life other than his personal.

This implies that the text based on autobiographical details despite creating invented story presents reality and the genuineness of the character that discloses itself in the production of the imaginary tale of her or his life. In the first-person narratives such as My Feudal Lord the "readers are made to overhear a murmuring internal voice of narration" (Miller, 2005). The narrative is told by a particular "I" that is repeatedly examining the essentials of the events as recounted, attempting to place them in a sequence, trying in particular to defend itself. This voice apparently converses to respond to the demand for narration. It seems, as if someone has commanded the narrator: "Account for yourself" (Miller, 2005). The storyteller talks as an eyewitness as Durrani speaks regarding her own life and on the subject of her ex-husband's sleaze and corruption as a witness.

The reciprocal interlocution amongst the individuals is mostly carried on by promises, declarations, accusations, or lies. Speech acts on these lines are very frequently used in one-on-one exchange of speech in My Feudal Lord. The major part of narration is made through the repeated sequence of Durrani's description in indirect speech and the lead characters speaking with one another in discourse are most often found confronting each other in turn to reconsider their point of view and character.

\subsection{Marital Communication}

Communication serves as a primary variable in comprehending matrimonial Interaction. Many studies have disclosed that matrimonial communication is a dominant predictor of marital stability and quality (Kerig \& Bacum, 2004; Halford et al., 2003; Gottman \& Notarious, 2002; Ridley et al., 2001). Consequently, most studies targeting marital interactions reveal the behaviors that are frequently visible in troubled than stable marriages (Rehman, 2003). Distressed couples are more hostile and critical, and more likely to deny responsibility, make excuses, complain and withdraw. On the other hand, non-distressed couples are found to be occupied with advanced degrees of care, approval, empathy, humor, positive oral prompts, and involvement.

Generally, the observed rate of recurrences of these oral prompts are coded, then employed to decide dominant or docile spouses. Though the coding design is dependable in its capacity to determine exact behaviors, the strength of the coding measures is harder to judge; there is inadequate research on the detailed theoretical rationale behind strategies employed to establish power differences. As Bales (1950) has not explained why particular observed actions such as 'gives suggestions' or 'shows solidarity' are considered to determine domination; instead these behaviors are purely associated with insight of authority. In addition, the basic measures employed in defining a person as dominant are self-referential as individuals who are defined 'dominant', 'act overtly towards others in a way that seems dominant' (Bales, Cohen, \& Williamson, 1979, p. 359). This does not provide any authentic causative structure for elucidating why or how some individuals turn out to be dominant. Being expert users of language, researchers depend upon decoding and interpreting language behavior (e.g., Donnelon, Gray, \& Bougon,1986; Gronn, 1983; Rosen, 1985).

Bearing in mind the paucity of studies on linguistic examination of matrimonial discourse which would concentrate on the printed discourse as an evidence of power relations instead of the actions of interlocutors as deciding factors of power, present study is an attempt to mark out the speech acts of Durrani and her husband Khar through the constructed dialogue of the couple in My Feudal Lord. This paper attempts to sketch the power dynamics as spotted through the use or nature of speech acts.

\section{Method}

Speech acts, found in Durrani's autobiography (1994), comprise the data for this study. The text selected for 
analysis, consists of constructed conversation involving the two main characters, Durrani and her husband Khar. The objective of this study is to explore the way power and gender norms are constructed and carried out by the female autobiographer through language.

Speech act theory of Searle (1970) has been applied to perform the analysis. Speech acts are elements of conversation that offer both reality and meaning. Searle described a speech act as speech that both depicts and is an act. By utilizing different forms of speech acts-for example statements, asking questions or giving commands - a person starts not only to work within his surroundings, but also relates with the world, he is surrounded by, and while doing so no only influences his own actions and attitudes but also of those he interacts with (Cooren, 2003).This study examined the illocutionary acts, suggested by Searle, such as representatives, commissives, directives, declarations, and expressive that emerge in the dialogues between Durrani and Khar in the autobiography.

The second section of the text, Lion of the Punjab, consisting of six chapters (out of a total of eighteen chapters), has been analyzed for this study. This section primarily covers the eleven years period of self-exile in London. During this period, Khar's political career was wedged and he remained with his wife and children for most of this period hence there are more instances of couple's dialogue than the other two parts of the book. This section also reveals Khar's attitude towards politics and life, his misuse of religious conviction, and his abuse of Durrani. Different speech acts in this section reveal the power relations through the conversations between the couple. The percentage of each category of speech acts produced for each speaker has been calculated. Declarative speech acts were not produced by the speakers, so this type has not been included in the analysis.

\section{Results and Discussion}

Khar's speech acts were analyzed first. He mostly employed commissives and directives which serve as an evidence of his control over his wife. The prominent aspect of Durrani's language was still the more recurrent use of directives as compared to Khar. Nevertheless, the main difference with reference to the use of directives was that Khar exercised more commands and Durrani posed more questions. Use of Commissives was another major difference which took place half of the times in Durrani's speech in comparison to that of Khar. In addition, he used the second person pronoun more often which is correlated in negative terms with relationship fulfillment and is correlated in positive terms with negative exchanges (Simmons et al., 2005). Another major difference was observed between the usage of you and we in the dialogues, within the selected data. You was found to be used 37-40 times in comparison to we which was never used by the speakers. Slatcher, Vazire and Pennebaker (2008) asserted that these words were labeled as emotional words and the use of these words served as indicators of shared identity, interdependence, and facilitative motivation. Gottman et al. (2002) have stated that reduced utterance of positive reactions in the conversation of couples is negatively linked with relationship fulfillment.

\subsection{Assertives}

The analysis of the selected data revealed that assertives were the most recurrently used speech acts. Assertives entrust the speaker to the exactness of the spoken proposition. The level of the conviction was observed to be comparatively strong in Khar's speech, substantiated by the use of expressions: I am sure ; I always thought ; I never thought (p. 133), I never picked her up (p. 149), I know you did (p. 161), You are, in any case, not mentally strong (p. 166), I forced you back (p. 252). Another prominent feature of Khar's speech acts was the use of offensive remarks and foul language when commenting on the family members of Durrani on a number of instances which indicate unequal power relations between the couple: I think I will discuss with your mother your misgivings about your relationship (p. 130), she (Durrani's sister) wants our marriage to break at any cost (p. 168), She's (Durrani's sister) mentally unwell, very unwell (p. 168), your mother is jealous of you (p. 246), your father won't throw a bone to you (p. 220), she (Durrani's mother) does not want this marriage to survive (p. 247).

Durrani also made use of assertives, however, they were weaker in nature. She expressed her own state of mind and belief even supposing she had a conflicting attitude, not in favor of belief of Khar nevertheless the differences in the expressions were evident: He's my brother, Mustafa, really (p. 133), But she's tired (p. 142), But, Mustafa, she's only a year and a half (p. 142), I thought... (p. 159), Nothing (p. 161), you sound more like a jealous lover (p. 175), Maybe you can help (p. 199). She conveyed her opinion as an appeal to clearing up her position by using neutral words like: really, but, I thought, may be to disagree with her husband's viewpoint. She says, you sound like, instead of openly describing him as a jealous lover. 


\subsection{Directives}

Directives indicate to the desire of the speaker to make the addressee perform some act. Ordering, inviting, requesting, challenging, and a number of other acts are included in this group. Directives, found occurring frequently in My Feudal Lord, include ordering, asking questions, wanting, and requesting. Both speakers are found asking questions in about all situations. Durrani poses more questions, 27 times, in contrast to Khar's quertions that were posed 22 times. She poses wh questions out of inquisitiveness: What happened last night? (p. 139), who is responsible? (p. 156), Where are the children? (p. 237), what would have happened if I did not come back to you? (p. 244). she uses non-wh question structures to decrease the outcome of a rebuttal: How can I call without my clothes? (p. 165), rather than plainly declining to obey the order as: why should I call without my clothes? Or I cannot call without my clothes. Similarly, she asks: How was I to guess that you wouldn't want to know him any longer - especially when he's in trouble (p. 199), rather than overtly stating that he has left his friend in sway. Another instance is: Do you really expect me to come out and hand myself over? (p. 214). She has a preference for a question structure to a statement to make her husband conscious that she is no stranger to his actions and intentions.

Khar, typically, asks why-questions to challenge Durrani's actions: Why did you speak to him for so long? (p. 133), Why have you come out (p. 139). He also asks questions to get assurance from Durrani to support him in critical time: Can you swear to dedicate your life to my cause and never remarry? (p. 251), if anything happens to me, do you swear to take up my cause? (p. 251), if I am assassinated like Bhutto, would you remain loyal and faithful to me?' (p. 251). Can you swear, do you swear, would you remain, are not the type of questions which do not inquire the information in the real sense instead these are close ended questions putting the addressee through a situation of affirmation or negation.

Requesting, another type of directive, took place in the selected data for twelve times. $2 \%$ of speech acts of Khar comprise requests whereas 3\% of speech acts of Durrani are based on requests. Requests of Khar aim at affecting Durrani's actions and behavior: Please don't believe her (p. 219), Please tell me (p. 219), Please forgive me for taking the children away from you (p. 241). Please don't leave me (p. 179), don't believe her, tell me, don't leave me, are implied commands whereas 'forgive me', is nevertheless a request. Durrani's requests reveal her vulnerability: Please believe me (p. 159), Let me wear this, please (p. 165), Please, Mustafa, for the sake of Prophet, let me wear my clothes (p. 165), But please be loyal to somebody (p. 176). She seeks permission by using the phrase, let me. In general, 'Let me', 'believe me' reflect the dependent status of speaker whereas 'be loyal' is a commanding directive synthesized with the addition of 'please' for politeness.

Commands were found to be used more frequently by Durrani, $16 \%$ of her total speech acts, as compared to Khar's commands which comprise $12 \%$ of his speech acts. Durrani uses lengthy, indirect speech to verbalize her arguments: I don't think that you should dare to lift your hand on me here! (p. 134), it's not right for you to talk to her alone in the middle of the night (p. 139), Tell her in no uncertain terms that you love me and the children (p. 182), I think you should leave us (p. 175), you don't need to do this (p. 213). Instead of saying, how dare you lift your hand on me here, or Don't talk to her alone in the middle of night, or Tell her that you cannot marry her. Leave us, Don't do this, she uses indirect commands to warn her husband. She employs conditional sentences to articulate her judgments and threats: 'If you feel that your commitment to Zeenat Aman is more sacrosanct than the one you made to me, go to her.' (p. 176), 'In that case, drop me off at my father's house.' (p. 182).

Imperatives are mostly employed by Durrani, such as, Learn to respect me and appreciate my living with you (p. 188), Tell her to get out of our lives (p. 182), Just put her into the car (p. 151), Think about it (p. 156), Sit down (p. 188), Talk to me like an adult (p. 188), Grow up (p. 188), Get that into your head (p. 188), Calm down (p. 215). There are a number of instances of her calling her husband by his given name to give commands in a polite manner: Mustafa, call Adila (p. 182), don't be foolish, Mustafa (p. 188), Forget it, Mustafa (p. 190). Generally, orders are given by those who enjoy power over the addressee. In this case, conversely, a woman of not as much of a controlling position is seen giving commands to the influential addressee as the circumstances permit her to do so. Though, nearly all of the commands, she gives are indirect, long and polite which are more like counsel to lay emphasis instead of a direct argument. In order to sound less odious and to add politeness, she addresses her husband using his first name.

Commands of Khar are, conversely short, compelling, and direct: Don't get involved (p. 123), Go back to sleep (p. 139), You can't take her out (p. 142), Answer me truthfully (p. 161), Make the call first (p. 165), Pick up the phone (p. 165), Come here (p. 175), Take the house in Islamabad (p. 177), Stop hallucinating (p. 201), Don't upset me (p. 213), Tell me (p. 219), Relax (p. 238), Come back to me (p. 241). On the other hand, Khar uses his wife's name to call her in only one out of his 36 commands: Tehmina, open the door now (p. 214), which does 
not even show politeness as he emphasizes on the compliance by showing urgency through the use of adverb now.

Another form of directives, found in the data, is personal desire or need statement. Khar uses 'I want' five times (pp. 198, 202a, 202b, 247, 251) in his speech, out of which, three relate to Durrani. Khar explains his needs or desires as: 'I want you to know/feel/decide', whereas, in Durrani's Speech, it appears no more than once: 'I want people to see me as I am.' (p. 216). Khar expresses his desire to make Durrani fulfill it. She, instead, desires to be herself, and a leader of her own self.

\subsection{Commissives}

The speaker obligates himself/herself to perform certain acts in Commissives. The instances of commissives found in the data are threats and promises. Even though they are found to be present in the language of both individuals, the rate of recurrence is half in Durrani's speech i.e., $6 \%$ as compared that of Khar which comprise $12 \%$ of the commissives. The first type of commissives that the data contain is promises. Khar makes promises to show his tendency to exercise authority: No matter what happens, I'll get Minoo back (p. 123), you'll see, I'll change and make it up to you (p. 132), Listen, I'll go back now and see what I can do (p. 238). Phrases like, no matter what happens, and you'll see, imply challenge. Some of his statements suggest as if he is making an offer or accepting a challenge: I'll do it (p. 245), I'll charter a flight and land in England (p. 245). While the rest of the examples speak about the course of his future life in the perspective of demonstrating devotion to his wife: I'll treat you like a queen (p. 179), I won't beat you anymore (p. 179), I'll be you slave (p. 179), I'll do your bidding - whatever pleases you (p. 179), I'll always love you (p. 176), I will never, ever let you down (p. 133).

Durrani, however, makes straight promises phrased as offers: I'll call (p. 165), I'll send a car for you (p. 238). She obligates herself to challenge her husband when he takes her children away: If you blackmail me, I'll blackmail you (p. 244), I will face up to the situation and fight you just as you are fighting me (p. 244), I will not let you get away with it (p. 244). Her expressions are squaring off as she indicates to her proposed plans as a product of her husband's undeserved treatment of her.

Another type of commissives, found in the data, was threats. Again, Khar uses threats twice as much as Durrani does. He threatens her of dreadful consequences: I shall not forgive you (p. 138), you will pay for this stupid act (p. 138), if you ever mention leaving again, I will not spare you (p. 189), You'll be picked up and I'll carry you back to the tribal area where there is no law (p. 245). He threats her of physical violence against her: I'll break every bone in your body (p. 188), I shall fling acid on your face (p. 189), I'll maim you and take my children away from you (p. 189), I can deprive you of your beauty like this (p. 189). Contrary to her other types of neutral speech acts, Durrani uses severe threats: The next time you raise your hand to me I will pick up a knife and kill you! (p. 188), I can tear that up whenever I feel like it (p. 188), if my face is bruised and battered, I shan't hide it (p. 216). Durrani's severe threats suggest that she is dismantling her subservience to her oppressive husband.

\subsection{Expressives}

The speech acts which put across the psychological condition about a situation specified in the prepositional substance are called expressives. The instances of this category of speech acts in the selected data are gratitude, reproach, compliments, and apology. There ratio in the use exprssives is 19:15 by Khar and Durrani respectively. Acknowledgements and compliments comprise the largest part of Khar's speech acts. He overtly expresses acknowledgement and gratitude to his wife: It has only been your love and devotion that has kept me sane (p. 132), everything around me has crumbled, but you've stood by me (p. 132), you're a strong woman (p. 133), you're the only woman who has the tolerance to cope with me intelligently (p. 133), I love you (p. 176), I would die without you (p. 176), I'll always love you (p. 176), I couldn't have had a more tolerant wife (p. 176), I don't know how I could have survived without you (p. 177), you are the only woman I can think of as a wife (p. 202), you are exceptional (p. 220), you've done the right thing (p. 252).

Durrani gives Khar compliment only once in the selected data: You have proved that I was wrong to think (p. 159). Compliment of Durrani is unlike the ones Khar expresses. Her compliment shows her obedience to Khar's forcefulness while compliments given by Khar are flattering, conventional and frank.

Khar apologizes directly by confessing his mistakes and indirectly by taking responsibility of his actions on several occasions: It is not really your fault, and I should have controlled my temper (p. 166), I've been a terrible husband (p. 176), I have made you suffer in exile (p. 176), I forced you to endure my fears and my problems (p. 176), I have put all my burdens on you, and you have carried them with dignity (pp. 176-177), whatever frustrations I've had, I've taken them out on you (p. 177). Thus, Khar admits and apologizes over his mistakes to control Durrani's actions; however, Durrani's only apology is visible in her statement: I'm really sorry (p. 132). 
Frequent reproach is found in the language of both characters. They frequently blame, criticize and accuse each other. Khar constructs negative assessments by stating: You embarrassed me (p. 138), You have humiliated me (p. 138), It's pure nonsense (p. 149), it's a strange world where you're condemned for your kindness (p. 154), this is not an atmosphere that I can afford in my home (p. 189), You talk too much (p. 198), Your attitude is becoming unacceptable (p. 214), your pregnancies are cursed (p. 225). Khar exerts his authority over his wife by misinterpreting her confession. He overtly questions the honesty of her request for forgiveness: Are you really sorry? (p. 159), Are you sincerely sorry? (p. 159), your tone is wrong (p. 159), You don't sound as if you're sorry (p. 159). Durrani, on the other hand, frequently expresses reproach indirectly: I'd like to see some sense of loyalty in you, for somebody, anybody - even another woman (p. 176), I find no necessary at all to live in this concentration camp (pp. 188-189), you sound terrible using such language (p. 189), It does not suit your status (p. 189), Mustafa, you're doing this deliberately (p. 213), you took me on a conducted tour of hell (p. 226). she, however, directly blames Khar in two examples: You have destroyed my life! (p. 163), you were irresponsible (p. 235).

Results signify that the speech acts used by Durrani and Khar in My Feudal Lord are both parallel and different in frequency. The speech of both characters is more or less representative of women's and men's speech features as identified by Holmes in 2000. He sums up, "Women's styles are indirect, conciliatory, facilitative, collaborative, talking..............as opposed to men's styles which are being direct, aggressive, competitive, autonomous, dominating, interrupting, and aggressive". Nevertheless, there are examples of limited or provisional power held by Durrani who otherwise was less dominant but she held control within less important incidents. She succeeded in controlling acts on her position contained by the situation or the circumstances, for instance she declines to admit apology of Khar by saying: 'Sorry is very inadequate word' (p. 190).

\section{Conclusion}

A major contribution of this study is to evaluate the use of the speech acts of different categories through analyzing the constructed conversation in My Feudal Lord. As the data indicate, both the speakers most commonly made use of directive and assertive speech acts. Khar was more liable to use commissives, directives and expressives as compared to Durrani. A speech act analysis of Durrani's language, based on Searle' model, indicates polite and indirect representatives employed by her in the story which prove her as a peaceful and collaborative person. The directives depict her as a considerate and sympathetic individual who values self-esteem and holds a desire for independence as she states: I want people to see me as I am (p. 216). Durrani has used more commands in particular and more directives in general even though she made use of a conflict avoidance approach and used polite expressions. The speech acts of Durrani falling in the category of commissives, disclose her character as both powerless and powerful. She employed smaller number of commissives however she warned Khar of serious outcomes which shows a constant development in her character leading to triumph over fear of her powerful husband. For example, she says: 'The next time you raise your hand to me I will pick up a knife and kill you!' (p. 188), 'If my face is bruised and battered, I shan't hide it' (p. 216). She warns him of a social, physical, and economic damage since an individual may lose his image in public if his abuse of his wife is brought on the surface. The expressives, conversely, represent her as a comparatively powerful person as she condemned Khar for ruining her life. She scarcely used any compliments or apologies which also demonstrate her receding obedience to Khar's power and lack of concern in showing any more dedication. The expressives, used by her, also reveal her strong courage and attitude to put herself in danger for condemning her husband.

Speech acts analysis of Khar's language demonstrates that his character has been depicted by the narrator as strong, aggressive and assertive. The analysis revealed that Khar made more use of explicit and powerful directives. Durrani's actions were called into question by him and he wanted reassurance of her loyalty in future which is an indication of his control over Durrani. His commissives represent him as a competitive, challenging, and boastful individual. He threatens Durrani to deprive her of her life, health, and beauty which reveals his violent attitude. He directly blames, complains, and criticizes Durrani and defends himself in his interactions to endorse his power and dominance. He openly used offensive language about the family of Durrani to demonstrate contempt for them and promote hostility in her mind about them.

For future studies, it will be significant to probe if there are gendered speech differences in different languages, and if so, how they function in different languages. It will be significant to carry out a comparative study of the same text translated into two different languages to distinguish how power dynamics vary according to the norms of gender and culture of a language. Moreover, further studies can analyze and compare speech acts in spoken and written language, and same gender or opposite-gender communications to investigate power relations. 


\section{References}

Adams, T. D. (1994). Introduction: Life writing and light writing; Autobiography and photography. MFS Modern Fiction Studies, 40(3), 459-492. https://doi.org/10.1353/mfs.1994.0011

Bales, R. F. (1950). Interaction Process Analysis: A Method for the Study of Small Groups. Addison-Wesley, Reading, MA.

Bales, R. F., Cohen, S. P., \& Williamson, S. A. (1979). SYMLOG: A System for the Multiple Level Observation of Groups. New York: Free Press.

Brown, R., \& Gilman, A. (1991). Politeness theory and Shakespeare's four major tragedies. Language in Society, 18, 159-212. https://doi.org/10.1017/S0047404500013464

Bruner, J. (1993). The Culture of Autobiography: Constructions of Self-Representation. California: Stanford University Press.

Chirrey, D. A. (2003). 'I hereby come out': What sort of speech act is coming out? Journal of Sociolinguistics, 7, 24-37. https://doi.org/10.1111/1467-9481.00209

Collett, A. (1989). Literature, Criticism, and Factual Reporting. Philosophy and Literature, 13(2), 282-296. https://doi.org/10.1353/phl.1989.0046

Cooren, F. (2003). The contribution of speech act theory to the analysis of conversation: How presequences work. Paper presented at the annual meeting of the International Communication Association, San Diego, CA.

Donnellon, A., Gray, B., \& Bougon, M. (1986). Communication, Meaning, and Organized Action. Administrative Science Quarterly, 31, 43-55. https://doi.org/10.2307/2392765

Durrani, T. (1995). My Feudal Lord. London: Transworld Publishers.

Exline, R., Ellyson, S., \& Long, B. (1975). Visual behavior as an aspect of power relationships. In P. Pliner (Ed.), Advances in the Study of Communication and Affect (pp. 21-52). New York: Plenum. https://doi.org/10.1007/978-1-4684-2835-3_2

Gottman, J. M., \& Notarius, C. I. (2000). Decade review: Observing marital interaction. Journal of Marriage and the Family, 62(4), 927-947. https://doi.org/10.1111/j.1741-3737.2000.00927.x

Gottman, J. M., \&. Notarius, C. I. (2002). Marital research in the 20th century and a research agenda for the 21 st century. Family Process Journal, 41, 159-179. https://doi.org/10.1111/j.1545-5300.2002.41203.x

Gottman, J. M., Swanson, C., \& Swanson, K. (2002). A general system theory of marriage: Nonlinear difference equation modeling of marital interaction. Personality and Social Psychology Review, 6(4), 326-340. https://doi.org/10.1207/S15327957PSPR0604_07

Gronn, E. (1983). Talk as the work: the accomplishment of school administration. Administrative Science Quarterly, 28, 1-21. https://doi.org/10.2307/2392382

Halford, W. K., Hahlweg, K., \& Dunne, M. (2003). The cross-cultural consistency of marital communication associated with marital distress. Journal of Marriage and the Family, 52(2), 487-500. https://doi.org/10.2307/353042

Holmes, J. (2000). Women at Work: Analyzing Women's Talk in New Zealand Workplaces. Australian Review of Applied Linguistics, 22, 1-17. https://doi.org/10.1075/aral.22.2.01 hol

Hudson, R. A. (1990). Sociolinguistics. New York: Cambridge University Press.

Jay, P. (1965). Field studies. In A. Schrier, H. F. Harlow \& F. Stollnitz (Eds.), Behavior of Nonhuman Primates: Modern Research Trends (pp. 525-592). New York: Academic Press. https://doi.org/10.1016/B978-1-4832-2821-1.50015-X

Kerig, P. K., \& Baucom, D. H. (2004). Couple Observational Coding System. London: Lawrence Erlbaum Associates. https://doi.org/10.4324/9781410610843

Lee, M., \& Ofshe, R. (1981). Impact of behavioral style and status characteristics on social influence: A test of two competing theories. Social Psychological Quarterly, 44(2), 73-82. https://doi.org/10.2307/3033703

Mazur, A. (1983). Hormones, aggression, and dominance in humans. In B. Svare (Ed.), Hormones and Aggressive Behavior. New York: Plenum. https://doi.org/10.1007/978-1-4613-3521-4_21

Miller, J. H. (2005). Literature as conduct: Speech acts in Henry James. Fordham University Press. 
Rehman, U. S. (2003). The association between communication behaviors and marital distress: A comparison of Pakistan, Pakistani immigrant, and white American couples. Unpublished $\mathrm{PhD}$ dissertation. Indiana University, USA

Ridgeway, C. (1984). Dominance, performance, and status in groups: a theoretical analysis. In E. Lawler (Ed.), Advances in Group Processes (pp. 59-93)., Greenwich, Conn.: JAI Press.

Ridley, C. A., Wilhelm, M. S., \& Surra, C. A. (2001). Married couples' conflict responses and marital quality. Journal of Social and Personal Relationships, 18, 517-534. https://doi.org/10.1177/0265407501184005

Risseeuw, C. (1988). The Fish Don't Talk About the Water. Gender Transformation, Power and Resistance among Women in Sri Lanka. Leiden: Brill.

Rosa, E., \& Mazur, A. (1979). Incipient status in groups. Social Forces, 58, 18-37. https://doi.org/10.1093/sf/58.1.18

Rosen, M. (1985). Breakfast at Spiro's: dramaturgy and dominance. Journal of Management, 11(2), 31-48. https://doi.org/10.1177/014920638501100205

Searle, J. R. (1969). Speech acts. Cambridge, UK: Cambridge University Press. https://doi.org/10.1017/CBO9781139173438

Searle, J. R. (1970). Speech acts: An essay in the philosophy of language. Cambridge, UK: Cambridge University Press. https://doi.org/10.1017/CBO9781139173438

Simmons, R. A., Gordon, P. C., \& Chambless, D. L. (2005). Pronouns in marital interaction: What do "you" and "I" say about marital health? Psychological Science, 16(12), 932-936. https://doi.org/10.1111/j.1467-9280.2005.01639.x

Slatcher, R. B., Vazire, S., \& Pennebaker, J. W. (2008). Am “I” more important than "we"? Couples' word use in instant messages. Personal Relationships, 15(4), 407-424. https://doi.org/10.1111/j.1475-6811.2008.00207.x

Spender, D. (1990). Extracts from Man Made Language, In D. Cameron (Ed.), The Feminist Critique of Language (pp. 91-318). London: Routledge.

Stobbe, L. (2000). Inclusion and Exclusion in the Argentine Auto Components Industry. A Study of Industrial Restructuring, Gender and Power. Saarbrücken: Verlag für Entwicklungs- politik Breitenbach.

Tannen, D. (1990). The Relativity of Linguistic Strategies: Rethinking Power and Solidarity in Gender and Dominance. In D. Cameron (Ed.), The Feminist Critique of Language (pp. 261-279). London: Routledge.

Tannen, D. (1990a). You just don't understand: women and men in conversation. New York: Morrow.

Woolf, V. (1990). Women and Fiction. In D. Cameron (Ed.), The Feminist Critique of Language (pp. 185-190). London: Routledge.

Woolf, V. (2004). The Angel in the House. In C. Shrodes, H. Firestone \& M. Shugrue (Eds.), The Conscious Reader (pp. 185-190). New York: Pearson Longman.

\section{Copyrights}

Copyright for this article is retained by the author, with first publication rights granted to the journal.

This is an open-access article distributed under the terms and conditions of the Creative Commons Attribution license (http://creativecommons.org/licenses/by/4.0/). 